\title{
Influence of Interest Rate on the Growth of Bond Markets in Kenya
}

\author{
Linet Amenya ${ }^{1}$, Prof Willy Muturi ${ }^{2}$, Dr, Oluoch Oluoch ${ }^{3}$, Dr. Assumpta Kagiri ${ }^{4}$ \\ 1.PhD Student, Department of Economics, Accounting \& Finance, JKUAT, Nairobi, Kenya, \\ linmoraa2003@gmail.com \\ 2.Professor, Department of Economics, Accounting \& Finance, JKUAT, Nairobi, Kenya, wmuturi@jkuat.ac.ke \\ 3.Lecturer, Department of Economics, Accounting \& Finance, JKUAT, Nairobi, Kenya, \\ josephat.oluoch@jkuat.ac.ke \\ 4.Lecturer, Department of Economics, Accounting \& Finance, JKUAT, Nairobi, Kenya, akagiri@jkuat.ac.ke
}

\begin{abstract}
:
Bond markets refers to the market where trading of debt securities takes place and contributes to the economy by providing an efficient economic system. The study established the influence of interest rate on growth of bond market. Additionally, the study examined the moderating effect of diaspora remittance on the combined relationship. The secondary data obtained from the CBK, KNBS and NSE was used in the study for a period of 20 years. The study employed descriptive research design. Time series regression model was applied where data was presented in form of tables and graphs. The study findings revealed that the interest rate had a strong positive influence on the growth of bond market. After introducing a moderator, the effect improved with significant $p$ value. The study found a positive significant relationship between interest rate and growth of bond markets in Kenya. It's therefore recommended that the CMA as a policy maker should improve on the policies that stabilizes the variability of interest rate. Further studies should also be carried out incorporating other macroeconomic variables not included in this study. Finally, the study also recommended that CBK should ensure that it improves on measures that control the interest rate variability as it influences the growth of bond market.
\end{abstract}

Keywords: Interest Rate, Bond Market Growth, Diaspora Remittance

DOI: $10.7176 / \mathrm{RJFA} / 13-3-03$

Publication date: February $28^{\text {th }} 2022$

\section{Introduction}

1.1 Background of the Study

Bond market growth is the main focus of greater economies that seek to raise capital for both investment and government expenditure. The bond market consists of both government and corporate bonds that shows a rapid growth rate, particularly in countries whose macroeconomic environments are stable and predictable (Ndunda, 2016). However, in countries characterized by volatile macroeconomic environment, they witness poor growth rate (Fabella \& Madhur, 2013).

The growth of bond markets contributes to the economy by providing an efficient economic system. It also attracts foreign investors due to greater investment opportunities and hence deepening the financial markets. The fundamental role of growth for bond markets is to promote the government and private sectors during the growth process. This ensures monetary policy direction, uniform interest rate across maturity range and the opportunity to hedge lending in bond market sector (Kahn, 2005). For a country to have effective growth rate in the bond markets, it requires favorable macroeconomic policies, existence of sound legal and regulatory framework, appropriate trading systems and significant participation of investors in the bond market (Ngugi \& Agoti, 2014).

Greenwood, Hanson and Stein (2010) in their study discovered that, the growth of bond markets in its early stages requires great effort of transparency in trading of securities and instrument design to strengthen and develop the short end of the market. However, Brouwer, (2002) comments on the significance of understanding a banking system that is free from political interference and operates on market principles as an important source of demand for the bond market. Yoshitomi and Shirai, (2001) observed effectiveness of banks ride on market-oriented rules and regulations governing the macroeconomic environment and as a result they gain stability and yields better growth rate. For instance, Australia, Korea, China, and Taipei after financial deregulation in the 1980s today, banks in these countries are major buyers of corporate bonds. Hence, a robust banking sector operating along market principles reinforces rather than weaken the bond market.

Kenya has instituted various changes over the years in the bond market to enhance the rate of growth in bond markets. Some of these changes include establishing a segment for fixed income trading securities at the securities exchange and tax incentives. These benefits enable investors to reduce the costs of transactions, coupled with diversifying the maturities mainly for treasury bonds and modernizing the trading system mainly for the treasury bonds to improve its performance through advanced technologies (siele, 2009).

Over the years Kenya government has made efforts to boost growth of the bond markets in 2001 among the efforts is the initiation of reforms that restructure the domestic bond market to ensure sustainable funding source 
of long term finances from both public and private sector (Ngugi \& Agoti, 2014), Nonetheless, the bond markets in Kenya still experience poor growth rate compared to peer companies in Africa. A stable strong and progressive bond market need to exhibit stable macroeconomic variables, efficiency, transparency, volatility coupled with minimal transaction costs (Galang \& Kalui, 2015).

(Nkwende, 2017) asserted that macroeconomic variables and banking sector development has negative and significant influence on the bond market capitalization and as such, they demonstrate strong evidence as robust macroeconomic influencers of bond market growth. Therefore, the study considered those factors as key promoter of growth in bond markets and strict monetary policies should be observed to control their effects on this sector.

Interest rate can be defined as the percentage cost of the principal charged for lending money to the borrower. Interest rates are usually charged per month or year (per annum) and its levels are determined by, and are directly proportional to the risk levels of the borrower. Thus, the amount borrowed should be invested in activities or use that generates more return than the lending rate so as to make economic sense (Doumpos \& Gaganis, 2012).

The interest rate refers to income paid for money borrowed. This rate also measures the rate of return expected by the lenders of the money in the market. It should therefore reflect all the information regarding future changes in the purchasing power and the risk undertaken in the market (Laopodis, 2015). Rate of interest has significant influence on the values of financial assets for example stocks and bonds (Alam \& Uddin, 2009). The interest rate and exchange rate in developing economies is likened to a coin of same side as low interest rate variability has persisted over the years. Consequently, the interest rate variability and exchange rate volatility perhaps may be responsible for the problem of poor growth rate in bond market (Ogilo, 2014). Mostly interest rate is unstable depending on the economy and affects the market value of the securities for instance; the bonds and the equities (Mainga, 2014).

Diaspora Remittances refers to transfer of money, goods and services by migrants back to their home country of origin or citizenship (Oucho, 2008). Remittances are a major source of external finances and can help to solve credit constraints or provide substitutes for the financial development of a country (World Bank, 2015). The effect of remittance inflows on the economic development of recipient countries centers on whether they are invested or consumed. If invested, remittances will generate a positive impact on growth and if consumed, it will either have an impact or not on growth of the economy (Burnside \& Dollar, 2010). The growth of remittance inflows in developing countries has generated tough debate and controversy among academicians and policy makers studying the contribution of remittances on the growth of bond markets (Adams \& Cuecuecha, 2010).

The growth of bond markets contributes to the economy by attracting foreign investors, providing an efficient economic system, greater investment opportunities, and deepening of the financial markets (Kahn, 2005). There is always an inadequacy of financial resources available for funding infrastructure projects on a long term basis in Kenya. This justifies that, there exist a financial gap and need arises to rely on other sources like bonds and concessions derived from private sector participation. Consequently, it is clear that the growth of bond markets is critical to stimulating economic growth particularly in developing economies like Kenya.

\subsection{Statement of the Problem}

Bond market growth has a positive influence in the development of a financial system and the economy of a country. This makes the growth of the bond market critical to financial system and economy of a country. Favourable macroeconomic policies, sound legal and regulatory framework and appropriate systems for trading leads to better growth of bond markets in a country (Ngugi \& Agoti, 2014).

In developed countries like America where the largest and the most developed bond market are found, statistics indicates that the bond market is dominated by the developed countries (ADB, 2009). The European bond market was estimated to comprise of 802.6 billion US dollars out of these 2 billion US dollars were from United Kingdom market (ECM, 2021). The sub-Saharan Africa bond market was estimated to have a size of 300 billion US dollars, out of which only 6.9186 billon were from the Kenyan bond market (CMA, 2020).

Most emerging bond markets, including Kenya are characterized by weak corporate mechanism, unstable macroeconomic environment, poor corporate governance, weak regulatory framework and unstable economic and political environment. This affects the confidence of local and foreign investors (Kemboi \& Tarus, 2012). The companies registered in the bond market as at December 2019 stood at 24 in Kenya while in South Africa and Middle East countries like Malaysia stood at 32 and 48 companies respectively (Yahya, Rahi \& Rashid, 2016). This depicts low participation of investors in the Kenyan bond market. As a matter of fact, this occurs as a result of unstable macroeconomic variables like interest variability and this may lead to poor growth in the bond market).

The government of Kenya took considerable efforts to enhance growth of the bond markets in 2001 In this year the Kenyan government commenced reforms to restructure domestic bond market to ensure sustainable funding source of long term finances from both public and private sector (Ngugi \& Agoti, 2014). Despite all these, the bond markets in Kenya still experience poor growth rate regardless of the observed steady growth rate of bond markets in the African context.

It is worth observing that. Kenya has always had a scarcity of financial resources available for funding 
infrastructure development projects on a long term basis. This is a justification that, there is need to rely on other sources like bonds to actualize the national government agenda. Consequently, it is clear that both the growth of government bond markets and the corporate bond markets are critical to stimulating economic growth particularly in developing economies like Kenya. This study therefore sought to fill this gap conducting a study on influence of interest rate on growth of bond markets in Kenya.

\subsection{Objectives \\ General Objective}

The general objective that guided the study was to investigate the influence of macroeconomic variables on growth of bond market in Kenya.

\section{Specific Objectives}

i. Assess the influence of interest rate on the growth of bond markets in Kenya.

ii. Examine the moderating influence of diaspora remittances on the relationship between interest rate and the growth of bond markets in Kenya.

\subsection{Literature Review}

Gruber and Kamin (2012) conducted a study on the relationship between short term interest rates, inflation, and GDP growth rate and government bond yields. Their study found that macro-economic aspects had a significant positive relationship with government bond yields and in reality the, overall increase in market interest rates would make a new bond less appetizing because the already existing bond would be paying better interest returns.

Smales (2012) investigated how interest rate influences the performance of bonds in the Australian market. This study used secondary data and found that interest rate affects the performance of bonds. The researcher concludes that after a scheduled macroeconomic announcement, the sensitivity to order flow went up in the Australian interest rate future markets and this attributes to an increase in the level of information asymmetry.

Vissing-Jorgense (2011) evaluated the effect of the Federal Reserve's purchase of long-term Treasury and other long-term bonds between 2008 and 2011 on interest rates. The study used an event-study methodology. The study revealed that Treasury rates should not be used as a policy target since it is inappropriate to focus only on Treasury rates as a policy target because it works through several channels that affect particular assets differently. We find evidence for a signaling channel, a unique demand for long-term safe assets, and an inflation channel.

Wuhan and Khursid (2015) investigated on how investment was affected in the country of China. Their main objective was to test how interest rate affects investment of Jiangsu province in China. Their study used secondary data that was obtained in a period of 10 years from the year 2003 to 2012 . Their study found that there was a negative relationship in the long run and a positive relationship in the short run. Their study further concluded that if the prices of bonds fall the interest rates moves upward.

Poghosyan (2013) also noted that interest rate has an influence on government bond yields. Conversely, interest rate refers to the rate of return on investment and the bond investor would always seek to earn most. Interest charged is the main cost of debt financing and their fluctuations should be investigated with respect to government bond yields.

Radier (2016) examined on the determinants of bond yield spread changes in South Africa. The study used a sample population of 106 corporate vanilla bonds listed on the South African market for the period 2005-2013. The study reported that changes in equity volatility, interest rate level and the yield curve slope are significant determinants of bond yield spreads. Also the study found that the effects of equity volatility and interest rate level were more pronounced during the mid-financial crisis period. The study confirmed that Controlling for credit ratings and bond convexity does not modify the findings.

Ndunda (2015) investigated on the effects of interest rates on bond yield in the Kenyan bond market. The study targeted 15 corporate bonds that were issued in a period of seven years from the year 2008 to 2014 . The study used secondary data and adopted the casual research design. The study adopted the liquidity premium theory of interest rate, market segmentation theory and preferred habitat theory. The study findings revealed that bond yield and interest rate risk has a positive relationship.

Ochieng (2015) conducted a study on the effects of interest rates on bond value at NSE. The researcher undertook a quasi-experimental research with time series data of nominal value of treasury gilt-edged bonds being regressed against the three regressors or interest rates using regression statistics. The study focused on interest rates, central bank rate, interbank rate and REPO rate where secondary data was used from 2008 to 2014 . The findings of the study revealed that CBR has a negative relationship with the nominal value of treasury gilt-edged bonds however IBR has a positive relationship with Repo rate. 


\subsection{Conceptual Framework}

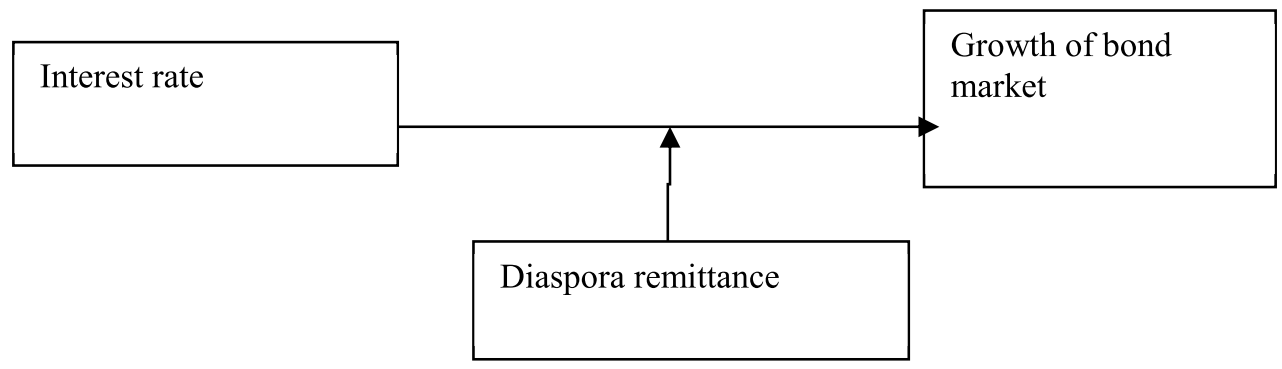

\section{Independent Variables Moderating Variable Figure 1: Conceptual Framework}

Dependent Variable

\section{Research Methodology}

The study employed a descriptive research design. The population of the study constituted the entire bond market that comprises of both corporate and government bonds issued and being traded at Nairobi Securities Exchange within the period of study. Monthly data was collected covering a period of 20 years between January 2000 and December 2019. Secondary data collection instrument was designed and used to collect the data from published reports by the CBK, NSE and KNBS where census survey was conducted. The data collected was cleaned, edited, coded and analyzed through the e-views \& stata software's. The regression models that guided the study include the following;

\section{Model I (without diaspora remittance interaction)}

$\mathrm{Y}_{\mathrm{t}}=\beta_{0}+\beta_{1} \mathrm{X}_{1 \mathrm{t}}+\beta_{2} \mathrm{Z}_{1 \mathrm{t}}+\varepsilon_{\mathrm{t}}$

Model 2 (with diaspora remittance interaction)

$\mathrm{Y}_{\mathrm{t}}=\beta_{0}+\beta_{1} \mathrm{X}_{1 \mathrm{t}}+\beta_{2} \mathrm{Z}_{1 \mathrm{t}}+\beta_{3} \mathrm{Z}_{1 \mathrm{t}} * \mathrm{X}_{1 \mathrm{t}}+\varepsilon_{\mathrm{t}}$

Where:

$\mathrm{B}_{\mathrm{o}}=$ Constant term (intercept),

$\mathrm{Y}_{\mathrm{t}}=$ Bond Market Growth at time $\mathrm{t}$,

$\beta$ - Parameters to be estimated

$\mathrm{X}_{1 \mathrm{t}}=$ Interest Rate at a time $\mathrm{t}$,

$\varepsilon \mathrm{t}=$ Error term or Stochastic error at time $\mathrm{t}$

$\mathrm{Z}_{1 \mathrm{t}}=$ diaspora remittances, $\varepsilon_{\mathrm{t}}=$

\section{Findings \& Discussions}

\subsection{Correlation Analysis}

Correlation analysis was conducted to determine the strength of the relationship between the study variables. From the findings reported in table 1 revealed that the bond market growth had a positive correlation with diaspora remittance $(r=0.633, p-$ value $<0.000)$. This implies that a positive change of diaspora remittance results to better growth rate of bond markets in Kenya. However, the correlation between interest rate and the growth of bond market was negative with a correlation coefficient of 0.080 and the $p$ value of 0.062 .

\section{Table 1: Correlation Matrix Test Results}

\begin{tabular}{llll}
\hline Probability & $\begin{array}{l}\text { Growth of bond } \\
\text { market }\end{array}$ & Interest rate & Diaspora remittance \\
\hline Growth of bond market & 0.100 & & \\
& ---- & & \\
Interest rate & -0.080 & 0.100 & \\
P-value & 0.062 & ---- & 1.00 \\
Diaspora remittance & 0.633 & 0.567 & ---- \\
p-value & 0.000 & 0.000 & \\
\hline
\end{tabular}

\subsection{Stationary Test.}

Stationary test is also known as unit root test. It was carried out by the study to determine the prevalence of time series data used in the study. If time series data is stationary, it displays constant mean and variance. If the data is non-stationary it may lead to bias outcomes. The study employed ADF statistical test to establish whether the variables were stationary or not 


\subsubsection{Bond Market Growth}

Table 2 showed the ADF test results of stationary test for bond market growth variable at level. From the results, the calculated t-statistic is -2.155809 which is less negative than the tabulated $t$-values at $1 \%, 5 \%$ and $10 \%$ significance level. The associated p-value was 0.2340 which is more than the cut-off value of 0.05 . However, the study accepted the null hypothesis therefore the bond market variable was non-stationary at level.

Table 2: Stationary Test Results of Bond Market Growth at Level

\begin{tabular}{|c|c|c|c|}
\hline \multirow{2}{*}{\multicolumn{2}{|c|}{ Augmented Dickey-Fuller test statistic }} & t-Statistic & Prob.* \\
\hline & & -2.155809 & 0.2340 \\
\hline \multirow[t]{3}{*}{ Test critical values: } & $1 \%$ level & -3.457865 & \\
\hline & $5 \%$ level & -2.873543 & \\
\hline & $10 \%$ level & -2.573242 & \\
\hline
\end{tabular}

\section{Stationary Test of Bond Market Growth at First Difference.}

Table 3 presents the ADF test results of stationary test for bond market growth variable at first difference. From the results, the calculated t-statistic value was -15.02559 which is more negative than the tabulated t-values at $1 \%, 5 \%$ and $10 \%$ significance level. The associated $p$-value is 0.0000 which is less than the cut-off value of 0.05 . However, the null hypothesis was rejected and the bond market variable was stationary at first difference.

Table 3: Bond Market Growth Stationary Test Results at First Difference

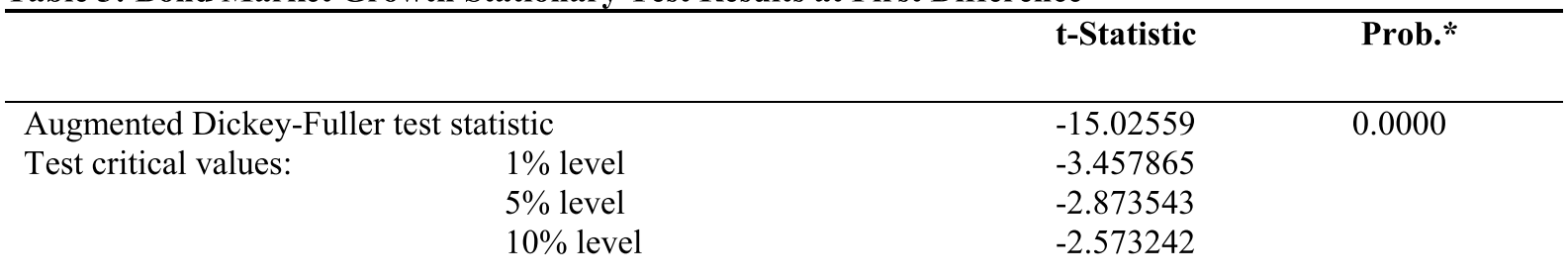

\subsubsection{Interest Rate}

Table 4 presents the Augmented Dickey-Fuller test results for stationary test of interest rate variable at level. From the results the calculated t-statistic is -2.740146 that was less negative than the tabulated t-values at $1 \%, 5 \%$ and $10 \%$ significance level. The associated p-value is 0.0704 which is more than the cut-off value of 0.05 . However, the null hypothesis is accepted and the interest rate variable was non-stationary at level

Table 4: Interest Rate Stationary Test Results at Level

\begin{tabular}{|c|c|c|c|}
\hline \multirow{2}{*}{\multicolumn{2}{|c|}{ Augmented Dickey-Fuller test statistic }} & t-Statistic & Prob.* \\
\hline & & -2.740146 & 0.0704 \\
\hline \multirow[t]{3}{*}{ Test critical values: } & $1 \%$ level & -3.457747 & \\
\hline & $5 \%$ level & -2.873492 & \\
\hline & $10 \%$ level & -2.573215 & \\
\hline
\end{tabular}

\section{Stationary Test of Interest Rate at First Difference.}

Table 5 presents the Augmented Dickey-Fuller test statistic for stationary test of interest rate variable at first difference. From the results above the calculated t-statistic values was -12.85711 which is more negative than the tabulated t-values at $1 \%, 5 \%$ and $10 \%$ significance level. The associated p-value is 0.0000 and less than the cutoff value of 0.05 . However, the null hypothesis is rejected and the interest rate variable was stationary at first difference.

Table 5: Interest Rate Stationary Test Results at First Difference

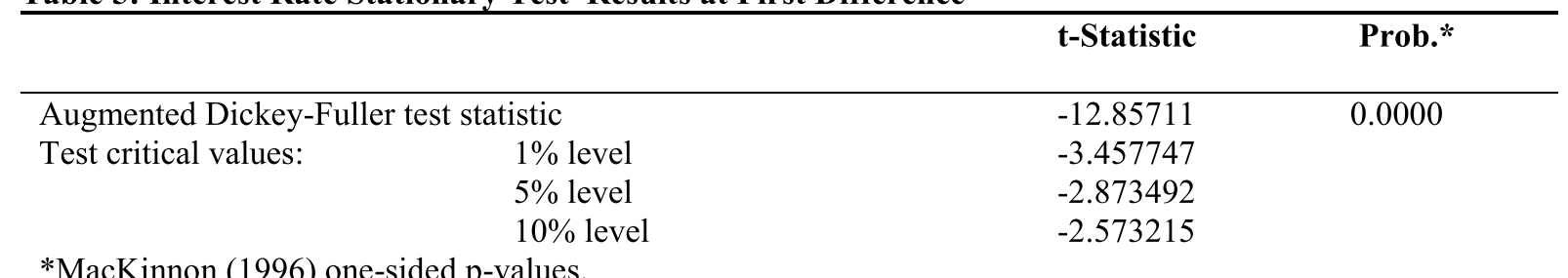

\subsubsection{Diaspora Remittances}

Table 6 presents the Augmented Dickey-Fuller test statistic for stationary test. The calculated t-statistic is less negative than the tabulated t-values. This implies that the Diaspora Remittances variable is non-stationary at level which implies differencing may be a viable option. The associated p-value was more than the cat-off value of 0.05 . However, the null hypothesis is accepted and the diaspora remittance variable was not stationary at level. 
Table 6: Diaspora Remittances Unit Root Test Results at level

\begin{tabular}{|c|c|c|c|}
\hline \multirow{2}{*}{\multicolumn{2}{|c|}{ Augmented Dickey-Fuller test statistic }} & t-Statistic & Prob.* \\
\hline & & -0.153908 & 0.9408 \\
\hline Test critical values: & $\begin{array}{l}1 \% \text { level } \\
5 \% \text { level } \\
10 \% \text { level }\end{array}$ & $\begin{array}{l}-3.458104 \\
-2.873648 \\
-2.573298\end{array}$ & \\
\hline
\end{tabular}

Stationary Test of Diaspora Remittance at First Difference.

Table 7 presents the output results for stationary test. The calculated t-statistic was more negative than the tabulated t-values. This implies that the diaspora remittances variable was stationary after the first difference action. The associated p-value was also less than the cat-off value of 0.05 . However, the null hypothesis is rejected and the interest rate variable was stationary at first difference.

Table 7: Diaspora Remittances Stationary Test Results at Level

\begin{tabular}{|c|c|c|c|}
\hline & & t-Statistic & Prob.* \\
\hline \multicolumn{2}{|c|}{ Augmented Dickey-Fuller test statistic } & -13.06458 & 0.0000 \\
\hline \multirow[t]{3}{*}{ Test critical values: } & $1 \%$ level & -3.458104 & \\
\hline & $5 \%$ level & -2.873648 & \\
\hline & $10 \%$ level & -2.573298 & \\
\hline
\end{tabular}

\subsection{Normality Test}

Normality test for residuals was conducted using the Jarque-Bera (JB) statistical method to determine whether the sample data has satisfied the normality assumption and whether the estimates are correct. Figure 2 indicates that the probability value for Jargue-Bera was 0.248135 that was greater than 0.05 . The study failed to reject the null hypothesis and therefore it was concluded that the residual takes normal distribution curve.
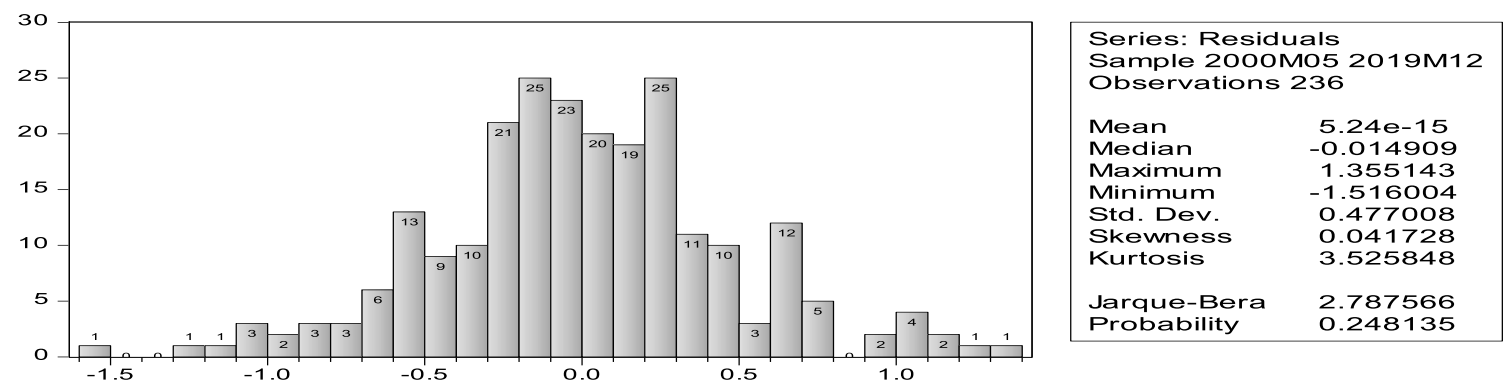

Figure 2: Residual Normality Test Interest Rate

\subsection{Autocorrelation Test}

From the results in table 8 , it's revealed that there is no problem of autocorrelation in the residuals since the $p$ values are insignificance. This is also an indication that the model is well and optimally identified.

Table 8: Autocorrelation Test Results of Interest Rate

\begin{tabular}{lllll}
\hline Lags & Autocorrelation & Partial Correlation & Q-Stat & Probability \\
\hline 1 & 0.093 & 0.093 & 2.1231 & 0.145 \\
2 & -0.054 & -0.063 & 2.8287 & 0.243 \\
3 & -0.035 & -0.024 & 3.1299 & 0.372 \\
4 & -0.077 & -0.075 & 4.5702 & 0.334 \\
5 & 0.012 & 0.023 & 4.6043 & 0.466 \\
\hline
\end{tabular}

\subsection{Heteroscedasticity test}

Heteroscedasticity test was conducted to establish whether the variability of the variables was not equal across a range of the predictor variables using Breusch-Pagan statistical method. Null hypothesis states that, there is constant variance across range of the predictor if the $p$ value is less than 0.05 . From

Table 9, revealed that the overall $p$ value attained was greater than 0.05 . This necessitates a constant variance and as a result the study fails to reject the null hypothesis. It's therefore concluded that heteroscedasticity does not exist which shows that the model is well identified. 
Table 9: Heteroscedasticity test

\begin{tabular}{|c|c|c|c|}
\hline \multicolumn{4}{|c|}{ Heteroskedasticity Test: ARCH } \\
\hline F-statistic & 1.652514 & Prob. F(2,235) & 0.1938 \\
\hline Obs*R-squared & 3.300797 & Prob. Chi-Square(2) & 0.1920 \\
\hline
\end{tabular}

\subsection{Model Summary}

Table 10 below presents the results on the fitness statistics. From the results it can be observed that $\mathrm{R}^{2}$ in model 1 and 2 was .742 and .763 respectively and the associated $P$ values in both models were significant. This implies that $74.2 \%$ in model 1 and $76.3 \%$ in model 2 of bond market growth can be explained by interest rate. However, $25.8 \%$ in model 1 and $23.7 \%$ in model 2 of bond market growth cannot be explained by interest rate. The results also show that the R- square change and F-change are statistically significant between model one and two. This shows that there is a significant moderation influence of diaspora remittances on the relationship between interest rate and growth of bond markets in Kenya.

Table 10: Model Summary Test Results for Interest Rate

\begin{tabular}{|c|c|c|c|c|c|c|c|c|}
\hline \multirow[t]{2}{*}{$\mathbf{R}$} & \multirow{2}{*}{$\begin{array}{l}\mathbf{R} \\
\text { Square }\end{array}$} & \multirow{2}{*}{$\begin{array}{l}\text { Adjusted } \\
\text { R Square }\end{array}$} & \multirow{2}{*}{$\begin{array}{l}\text { Std. Error } \\
\text { of the } \\
\text { Estimate }\end{array}$} & \multicolumn{2}{|c|}{ Change Statistics } & \multirow[b]{2}{*}{ df1 } & \multirow[b]{2}{*}{ df2 } & \multirow[b]{2}{*}{$\begin{array}{l}\text { Sig. F } \\
\text { Change }\end{array}$} \\
\hline & & & & $\begin{array}{l}\text { R } \\
\text { Square } \\
\text { Change }\end{array}$ & $\begin{array}{l}\text { F } \\
\text { Change }\end{array}$ & & & \\
\hline .862 & .742 & .740 & .7569564 & .701 & 645.261 & 1 & 237 & .000 \\
\hline .873 & .763 & .760 & .7279316 & .020 & 20.277 & 1 & 236 & .000 \\
\hline
\end{tabular}

\subsection{Analysis of Variance}

Table 11 showed the ANOVA test results and it revealed that interest rate significantly influences the bond market growth since the $\mathrm{p}$ value is less than 0.05 . The regression analysis result confirms that the overall regression model significantly predicts the growth of bond market. This implies that statistically the applied model can predict the changes in the growth of bond market. For all the two models the results disclose that the variables employed are relevant in the explanation of the bond market growth.

Table 11: Analysis of Variance Test Results for Interest Rate

\begin{tabular}{lllllll}
\hline Model & & Sum of Squares & df & Mean Square & F & Sig. \\
\hline 1 & Regression & 391.431 & 2 & 195.715 & 341.573 & 0.000 \\
& Residual & 135.797 & 237 & 0.573 & & \\
& Total & 527.228 & 239 & & & 0.000 \\
\hline 2 & Regression & 402.175 & 3 & 134.058 & 252.995 & \\
& Residual & 125.053 & 236 & 0.530 & & \\
& Total & 527.228 & 239 & & & \\
\end{tabular}

\subsection{Overall Regression Model}

Table 12 presents the regression results on coefficients of moderated interest rate. In the first model, the interest rate was combined with diaspora remittance and the beta values was $(\beta=0.614, t=2.061, P$-value $=0.040)$. This implied that interest rate contributed an index of 0.614 to effectiveness of the growth in the bond market. The beta value of diaspora remittance was $(\beta=1.366, \mathrm{t}=25.402, \mathrm{P}$-value $=.000)$ and the study concluded that diaspora remittance was a significant predictor in the model.

In the second model, the interaction term $\left(\mathrm{X}_{1 \mathrm{t}}{ }^{*} \mathrm{Z}_{1 \mathrm{t}}\right)$ was introduced with it the beta value for interest rate increased significantly from $(\beta=0.614, \mathrm{t}=2.061, \mathrm{P}$-value $=0.040)$ to $(\beta=24.800, \mathrm{t}=4.388, \mathrm{P}$-value $=0.000)$ and therefore statistically significant. The beta values of diaspora remittance were $(\beta=1.801, t=2.554, P$-value $=0.011)$ and as such the study reached a conclusion that diaspora remittance was a significant moderator in the model. Thus this section concludes that diaspora remittance variable was a relevant moderator for interest rate. These findings agreed with the findings of Wuhan and Khursid (2015) and Ndunda (2015).

The model equations are;

$$
\begin{array}{ll}
\text { Model 1: } & \mathrm{Y}_{\mathrm{t}}=9.128+0.614 \mathrm{X}_{1 \mathrm{t}}+1.366 \mathrm{Z}_{1 \mathrm{t}}+\varepsilon_{\mathrm{t}} \\
\text { Model 2: } & \mathrm{Y}_{\mathrm{t}}=60.443+24.800 \mathrm{X}_{1 \mathrm{t}}+1.801 \mathrm{Z}_{1 \mathrm{t}}+1.158 \mathrm{Z}_{1 \mathrm{t}} * \mathrm{X}_{1 \mathrm{t}}+\varepsilon_{\mathrm{t}}
\end{array}
$$


Table 12: Coefficients for Moderated Interest Rate

\begin{tabular}{llllll}
\hline Model & & Coefficients & & t-statistics & p-value \\
\hline 1 & B & Std. Error & & .000 \\
& Interest rate & 9.128 & 1.648 & 5.538 & .040 \\
& Diaspora remittances & 1.366 & 0.298 & 2.061 & .000 \\
\hline 2 & (Constant) & 60.443 & 0.054 & 25.402 & .000 \\
& Interest Rate & 24.800 & 5.651 & 3.892 & .000 \\
& Diaspora remittances & 1.801 & 0.705 & 4.388 & .011 \\
& Diaspora remittances & 1.158 & 0.257 & 2.554 & .000 \\
& *interest rate & & & 4.503 & \\
\hline
\end{tabular}

\section{Conclusion}

From data analysis results and the resultant findings, the study concluded that interest rate significantly influences the growth of bond markets in Kenya. Based on the regression analysis the study concluded that interest rate positively and significantly influences the bond market growth in Kenya. Consequently, the high interest rate leads to a better growth rate in the bond market. Further the study concluded that diaspora remittance was a significant moderator Thus these findings corroborated with those of Ochieng (2015 and Njoroge (2013).

\section{Recommendations}

The study recommended that the government of Kenya through the CBK should formulate favourable policies and measures that helps in controlling and stabilizing the variability of interest rate as this forms an important aspect since it creates confidence in investors and avoids exploitation in the bond market sector. Since the study found that diaspora remittance has a positive significance moderating influence, it's therefore recommended that the government of Kenya should institute aggressive campaigns targeting people living in diaspora to educate them on the importance of investing back at home. Finally, the national assembly therefore needs to provide a conducive environment for diaspora investors through formulation of favorable investment policies.

\section{References}

Adhikari, D. R., \& Guru-Gharana, K. K. (2014). An econometric study of the effect of remittances on inflation in India. Journal of International Business Research, 13(1), 105.

Ahwireng-Obeng, A. S., \& Ahwireng-Obeng, F. (2019). Macroeconomic determinants of sovereign bond market development in African emerging economies. International Journal of Emerging Markets.

Andere, C. (2017). Establishing the Causal Relationship between Inflation and Yield Curve Movements in Kenya for the Period Between 2010 to 2016 (Doctoral dissertation, United States International University-Africa).

Bekaert, G., Engstrom, E., \& Grenadier, S. R. (2010). Stock and bond returns with moody investors. Journal of Empirical Finance, 17(5), 867-894.

Bhattacharyay, B. N. (2013). Determinants of bond market development in Asia. Journal of Asian Economics, 24, 124-137.

Blumberg, B., Cooper, D., \& Schindler, P. (2014). EBOOK: Business Research Methods. McGraw Hill.

Brickman Bhutta, C. (2012). Not by the book: Facebook as a sampling frame. Sociological methods \& research, 41(1), 57-88.

Campbell, J. Y., Lo, A. W., \&MacKinlay, A. C. (2012). The econometrics of financial markets.princeton University press.

Central Bank of Kenya, 2017). The Kenya Finacial sector stability report. Published by the Financial Sector Regulators Forum, September 2018, Issue No. 9

Galang and Kalui (2015). The relationship between earnings announcements and stock prices at the Nairobi securities exchange. Journal of economics, commerce and management, 6(1), 166-167

Gallagher, L. A., \& Taylor, M. P. (2002). The Stock Return-Inflation Puzzle Revisited. Economics Letters, 75(2), $147-156$

Ganatra, S. (2016). Factors Affecting the Performance of Infrastructure Bonds in Kenya: A Case of Kengen Infrastructure Bond (Doctoral dissertation, United States International University-Africa).

Githinji, W. A. (2013) Effect of selected macroeconomic variables on bond market development in Kenya. Unpublished MBA Thesis, Nairobi: University of Nairobi.

Hondroyiannis, G., \&Papapetrou, E. (20155). An examination of Wagner's law for Greece: A cointegration analysis. Public Finance = Finances publiques, 50(1), 67-79.

Hussain, S., \& Malik, S. (2011). Inflation and economic growth: Evidence from Pakistan. International Journal of Economics and Finance, 3(5), 262-276.

Igbarago, M. E., \&Eromosele, H. O. (2016). Econometric analysis of the effect of inflation on investment in 
Nigeria. International Journal of Business \& Economics Perspectives, 11(1).

Ishak, N. M., Bakar, A., \&Yazid, A. (2014). Developing Sampling Frame for Case Study: Challenges and Conditions. World Journal of Education, 4(3), 29-35.

Kahn, B. (2005). Original sin and bond market development in Sub-Saharan Africa. Africa in the world economy: The national, regional and international challenges, 67-87.

Kamenju, C. I. (2018). Effect of Macroeconomic Factors On the Development of Bond Market in Kenya (Doctoral dissertation, University of Nairobi).

Kariuki W. N. \&Kagiri A. (2016).Effect of inflation on Aggregate Bond performance in Nairobi Securities Exchange in Kenya.International Journal of management and commerce innovations, 4(2), 288-294.

Kemboi, J. K. \&Tarus, D. N (2012). Macroeconomic Determinants of Stock Market Development in Emerging Markets: Evidence from Kenya. Research Journal of Finance and Accounting, 3(5).

Kullapom, L., \&Lalita, R. (2010). Relationship between Inflation and Stock Prices in Thailand (Doctoral dissertation, Master's Thesis, Umea University, Sweden).

Lee, C. M. (2001). Market efficiency and accounting research: a discussion of "capital market research in accounting'by SP Kothari. Journal of Accounting and Economics, 31(1-3), 233-253.

Longei, H. (2017). Determinants of bond market index at the Nairobi securities exchange in Kenya. Strategic journal of business \& change management, 4(4), 58-69.

Modigliani, F., \& Cohn, R. A. (1979). Inflation, rational valuation and the market. Financial Analysts Journal, $35(2), 24-44$.

Mohammad, B.A. (2011) "Impact of Micro and Macroeconomic Variables on Emerging Stock Market Return: A Case on Dhaka Stock Exchange (DSE)", Interdisciplinary Journal of Research in Business.

Mukiza, C. N. (2011). Current Inflation Trends: Main Drivers. Causes and Policy Implications, Uganda Bureau of Statistics Staff Working Papers.

Newing, H. (2010). Conducting research in conservation: social science methods and practice. Routledge.

Ngaruiya, M., \&Njuguna, A. (2016). Influence of Inflation on Bond Prices: A Survey of Bonds Listed at the Nairobi Securities. American Journal of Economics, 1(2), 50-63.

Ngaruiya, M., \&Njuguna, A. (2016). Influence of Inflation on Bond Prices: A Survey of Bonds Listed at the Nairobi Securities. American Journal of Economics, 1(2), 50-63.

Ngugi, R. W. And Agoti, J. (2014). Microstructure elements of bond markets in Kenya. African conference paper, 46 KIPPRA Discussion Paper No.027, Nairobi: Kenya Institute for Public Policy

Ngugi, S.M. \& Afande, F.O. (2015). Drivers for Issuance of Corporate Bonds by Listed Companies in Kenya. Developing Country Studies, 5(7), 143-64.

Ritter, J. R. (2012). Is Economic Growth Good for Investors? 1. Journal of Applied Corporate Finance, 24(3), 818.

Riungu, J. (2016). A Survey of Factors Determining Development of Corporate Bonds Market in Kenya Unpublished MBA thesis, Nairobi: University of Nairobi.

Saunders, M., Lewis, P. H. I. L. I. P., \&Thornhill, A. D. R. I. A. N. (2007). Research methods. Business Students 4th edition Pearson Education Limited, England.

Shiblee, L. S. (2009). The impact of inflation, GDP, unemployment, and money supply on stock prices. GDP, Unemployment, and Money Supply On Stock Prices (December 29, 2009).

Siele, W. (2009). Study on the relationship between bond market return and some selected macroeconomic variables in Kenya. Unpublished MBA Thesis, Juja: JKUAT.

Tabachnick, B. G., Fidell, L. S., \& Ullman, J. B. (2007). Using multivariate statistics (Vol. 5, pp. 481-498). Boston, MA: Pearson.

Tala, L. (2017). Fiscal, Deficit, Inflation, Money Supply and Exchange Rate in South Africa (Doctoral dissertation, Nelson Mandela University).

Wanyama, D. W. (2017). Effect of stock market volatility on the growth of corporate bond market in Kenya. International Journal of Finance, 2(2), 76-91.

Wei, C. (2009). Does the Stock Market React to Unexpected Inflation Differently Across the business cycle? Applied Financial Economics, 19(24), 1947-1959. 